\title{
Discussion on Activation of Youth Service Learning Based on Linkage Between School and Community: Focusing on Human Resources and Operational Aspects
}

\author{
Jihyun Park1)
}

\begin{abstract}
This study proposed an activation plan for youths to participate in meaningful service learning. Specifically, this study analyzed human resources and operational improvement measures to support service learning for middle and high school students in connection with schools and communities. Interviews, Delphi investigations, and expert council research methods were performed. The subjects of the study were a total of 30 people, including teachers in charge of service learning at the school, administrators of out-of-school service learning centers, service learning operators, and people involved in local service organizations. As a result of the study, the competency required for service learning, measures to cultivate these competencies, plans to establish a cooperative system among institutions, and various other support systems were proposed. Based on these results, the importance of educational cooperation, the need for skilled workers for service learning, the active role of teachers, and the need to provide sufficient information were discussed.
\end{abstract}

Keywords: Service Learning, Youth, School, Community

\section{Introduction}

In elementary school, middle school, and high school, various learning is performed outside of regular classes, one of which is 'service learning'[1]. Service learning allows students to participate in systematic and planned volunteer activities, thereby equipping them with democratic citizenship capabilities such as sharing and consideration[2][3]. In addition, it is an activity that aims to solve problems in the community and lead a life of living together[4][5]. In other words, students voluntarily perform various volunteer activities outside of the regular classes of the school[6][7], and such service learning is also important in schools because it is also used as a college entrance material[8][9].

However, students' service learning still has limitations in many ways. Since it is not a

Received(April 22, 2020), Review Result(1st: June 6, 2020, 2nd: July 24, 2020), Accepted(August 28, 2020)

1) (Associate Professor) 61204 Dept. of Music Education, Gwangju National University of Education, Pilmundaero Buk-gu, Gwangju, Korea

email: jhp@gnue.ac.kr 
Discussion on Activation of Youth Service Learning Based on Linkage Between School and Community. Focusing on Human Resources and Operational Aspects

regular class, it is relatively less important in school. As a result, there is a disadvantage that service learning cannot be systematically conducted[10]. In addition, volunteer learning is conducted through the guidance of volunteers, not school teachers, so there is a limit to the educational learning that is conducted[11]. In addition, there are difficulties in practical operation such as time management, administrative support, and budgeting[12][13]. However, schools do not only improve students' intellectual abilities, but they also have a duty to improve their emotional abilities appropriately. In addition, in order to cultivate diverse capacities for students to live well in the future society, efforts should be made to provide students with a variety of experiences outside of regular classes.

In this regard, this study aimed to examine the improvement measures to ensure that the service learning at school is well executed. Since service learning is related to the ability to live well in the future, the focus is on service beyond the school service and in connection with the community outside the school. In other words, the researcher would like to suggest an improvement plan to better perform service learning in connection with the community outside the school. These improvement measures were divided into human and operational aspects. In the human aspect, it was proposed to develop professionalism such as school personnel and volunteers who lead service learning, and in the operational aspect, to establish a support system and conditions.

\section{Theoretical Background}

It has been more than 20 years since service learning has been established in Korean school education. In the early days, it was a 'volunteering activity' focusing on 'activity' rather than a 'learning' aspect, and time such as how long you participated in the service was important. In other words, the initial volunteer activities remained simple, such as filling in time and building specifications, but recently, these problems have been overcome, and students have become interested in 'learning', a service that students can participate in and sustain with meaning[14-16]. In other words, it aims at service learning that recognizes the value of sharing and consideration and nurtures the character that lives with the future society[17], service learning linked to school classes, and service learning that possesses the virtues of future democratic citizens. 


\section{Research Method}

The subjects of the study were a total of 30 people, including teachers in charge of service learning at the school, administrators of out-of-school service learning centers, actual service learning management mentors, and community service group operators. First, interviews were conducted for four times in August-September 201 to draw out the current operational problems in service learning. Subsequently, a Delphi investigation and expert council was held to examine ways to improve the problems identified through the interviews. The Delphi survey was conducted three times in October-November 2019 for 15 experts related to service learning, and divided into human and operational aspects to collect expert opinions on improvement measures. The Delphi survey questions consisted of the competence needed for those in charge of service learning, improvement measures to strengthen competency, measures to establish a cooperative system among institutions, and plans to establish various conditions and support systems. Finally, the researcher conducted an expert council twice in January 2020 to review the overall effectiveness of the school service learning improvement plan.

\section{Results}

\subsection{Results of Interview Analysis on Problems in Service Learning Operation}

The following [Table 1] summarizes the problems in service learning management derived through interviews.

[Table 1] Results of Analyzing Problems in Service Learning Operation through Interviews

\begin{tabular}{|c|c|c|}
\hline Category & Teacher in school & Out-of-school service learning center/mentor/service group \\
\hline \multirow{2}{*}{$\begin{array}{l}\text { The goal } \\
\text { of service } \\
\text { learning } \\
\text { a n d } \\
\text { content }\end{array}$} & \multicolumn{2}{|c|}{$\begin{array}{l}\text { - Service learning to nurture student self-direction } \\
\text { - Service learning that provides an opportunity to reflect on life } \\
\text { - Service learning as a pathway to connect life with learning } \\
\text { - Service learning that is linked to the curriculum to lead student growth }\end{array}$} \\
\hline & & - Connection of service learning process and fruition \\
\hline $\begin{array}{l}\text { Culture } \\
\text { a } \quad \mathrm{n} \quad \mathrm{d} \\
\text { climate }\end{array}$ & \multicolumn{2}{|c|}{$\begin{array}{l}\text { - Need to raise teacher awareness in school } \\
\text { - Insufficient awareness of the principal's service activities }\end{array}$} \\
\hline Budget & \multicolumn{2}{|c|}{ - Insufficient budget and difficulty in using budget } \\
\hline Operation & \multicolumn{2}{|c|}{ - No cooperation and communication system between school and autonomous regions } \\
\hline
\end{tabular}




\begin{tabular}{|l|l|}
\hline & $\begin{array}{l}\text { - Difficulty in coordinating schedules between schools and centers } \\
\text { - Lack of human resources and lack of expertise } \\
\text { - Difficult to activate service learning outside school due to safety issues }\end{array}$ \\
\hline & $\begin{array}{l}\text { - Difficulties in the process of service learning and progress } \\
- \text { Complaints about whether or not to reflect the school } \\
\text { records } \\
\text { - Difficulty in reflecting school and student demands for } \\
\text { service activities }\end{array}$ \\
\hline
\end{tabular}

\subsection{Improvement Measures in Terms of Human Resources in Charge of Service Learning: Competency Dimension}

In order to address the above problems, first, it is considered that the professionalism of the service learning personnel needs to be improved. First, it requires competence related to service value, which is to understand the meaning, value, and role of service learning, and to have relevant consciousness. Second, competencies related to the understanding of school education are needed, which are about understanding the school education goals, situations, and curriculum. Third, competencies related to student understanding are required, which is an understanding of the developmental and academic aspects of adolescent students. Fourth, competency related to content expertise is required, which is to have expertise in service topics or content to be performed. Finally, competency related to education expertise is needed, which is related to effectively planning, operating, and evaluating service classes and creating a learning environment and culture. Based on the above five competencies, the following [Table 2] specifically presents the competencies required for school teachers, out-of-school service center administrators, and service practitioners.

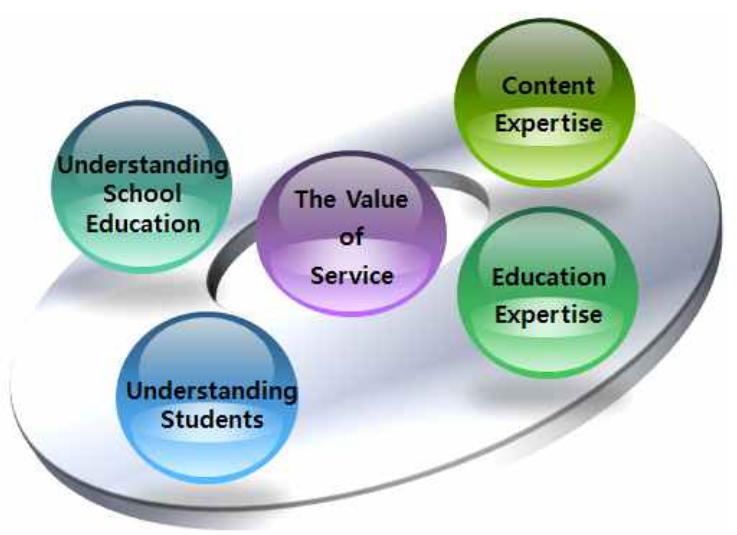

[Fig. 1] Competency Required for Service Learning Operators 


\subsection{Improvement Measures in Terms of Human Resources in Charge of Service Learning: Member Level}

Support measures were reviewed to improve the competency of those who practice volunteer learning. The results are as follows [Table 2].

[Table 2] Ways to Complement Human Resources and Strengthen Competencies

\begin{tabular}{|c|c|c|}
\hline $\begin{array}{c}\text { Categor } \\
\mathrm{y}\end{array}$ & Main plan & Contents \\
\hline \multirow{3}{*}{$\begin{array}{l}\text { Operato } \\
\mathrm{r}\end{array}$} & $\begin{array}{l}\text { Empowerment of } \\
\text { teachers and } \\
\text { principals }\end{array}$ & $\begin{array}{l}\text { In order to raise awareness about service learning, it is necessary to } \\
\text { activate school consultation. } \\
\text { It is necessary to spread the culture of discussion to link the } \\
\text { contents of service learning to the existing curriculum or work } \\
\text { discussion through organization of learning such as the teacher } \\
\text { community. }\end{array}$ \\
\hline & $\begin{array}{l}\text { Assignment of } \\
\text { a dministrative } \\
\text { personnel in charge } \\
\text { of service in } \\
\text { schools and school } \\
\text { boards }\end{array}$ & $\begin{array}{l}\text { It is necessary to allocate dedicated personnel to continuously take } \\
\text { charge of service learning in schools and school boards. } \\
\text { In other words, service learning administration is continuously } \\
\text { assigned to administrators who have relatively long cycles of duty, in } \\
\text { addition to the teachers and scholars in charge. }\end{array}$ \\
\hline & 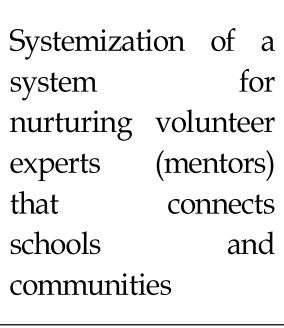 & $\begin{array}{l}\text { Since the role of people is very important in the network with } \\
\text { schools that want to learn service, a system for training professional } \\
\text { personnel to lead and connect with the school's service learning is } \\
\text { required. } \\
\text { In other words, it is responsible for safety management, activity } \\
\text { initiation, and implementation, and systematically fosters professional } \\
\text { personnel to be connected, ultimately establishing a } 1 \text { school } 1 \text { expert } \\
\text { (mentor) system }\end{array}$ \\
\hline \multirow[b]{2}{*}{$\begin{array}{l}\text { Participa } \\
\text { nts }\end{array}$} & $\begin{array}{l}\mathrm{N} \text { u r t u r i n g } \\
\text { parent-centered } \\
\text { volunteer coaching } \\
\text { as a human bank }\end{array}$ & $\begin{array}{l}\text { Ways to keep parents engaged in school service activities, not just } \\
\text { one-time events } \\
\text { Establish ways to involve parents more actively by negotiating with } \\
\text { each other the part to be supported and the part to be supported }\end{array}$ \\
\hline & $\begin{array}{l}\text { Support for } \\
\text { student-centered } \\
\text { service learning } \\
\text { discussions }\end{array}$ & $\begin{array}{l}\text { Effectiveness and satisfaction are maximized when students' } \\
\text { participation, spontaneity, and needs are reflected, and student } \\
\text { service learning leads to meaningful results such as donations. } \\
\text { Therefore, student self-government organizations, such as school year } \\
\text { meetings and school-wide meetings, discuss service learning and } \\
\text { related curriculum to increase student initiative and spontaneity. }\end{array}$ \\
\hline
\end{tabular}

\subsection{Improvement Measures in Terms of Service Learning Operation: Cooperation System} Level

The method of establishing a cooperation system in terms of operation is as shown in [Table 
3].

[Table 3] Ways to Build a Cooperative System

\begin{tabular}{|c|c|c|}
\hline Category & Main plan & Contents \\
\hline \multirow{2}{*}{ In school } & $\begin{array}{l}\text { Formation of a service } \\
\text { learning teacher council } \\
\text { within the school }\end{array}$ & $\begin{array}{l}\text { Organize a teacher-centered council to plan service } \\
\text { learning within the school and reflect on the results }\end{array}$ \\
\hline & $\begin{array}{l}\text { Establish collaborative } \\
\text { governance of students, } \\
\text { parents, and teachers }\end{array}$ & $\begin{array}{l}\text { Establish a council to communicate between students and } \\
\text { parents, who are the main subjects of service learning, } \\
\text { and teachers who plan and operate service learning }\end{array}$ \\
\hline $\begin{array}{l}\text { School } \\
\text { school }\end{array}$ & $\begin{array}{l}\text { Formation of inter-school } \\
\text { councils in autonomous } \\
\text { districts }\end{array}$ & $\begin{array}{l}\text { Cooperative planning and operation of various volunteer } \\
\text { activities through linkage between schools to share } \\
\text { schedules, and balanced volunteer activities within the } \\
\text { same area } \\
\text { In addition, each school's service learning results are } \\
\text { shared with other schools. }\end{array}$ \\
\hline \multirow{2}{*}{$\begin{array}{l}\text { B e } t \mathrm{w} \text { e e } \mathrm{n} \\
\text { school and } \\
\text { region }\end{array}$} & $\begin{array}{l}\text { Education cooperation } \\
\text { network between school } \\
\text { and autonomous district } \\
\text { c e } \mathrm{n} t \mathrm{e} \mathrm{r}-\mathrm{E} \mathrm{d} \mathrm{u} \text { c a t i o } \mathrm{n} \\
\text { office-community }\end{array}$ & $\begin{array}{l}\text { It is necessary to ensure close communication, such as } \\
\text { regular meetings and meetings between schools and } \\
\text { autonomous districts, venues for sharing service learning } \\
\text { results, and providing opportunities for the center to } \\
\text { promote. }\end{array}$ \\
\hline & $\begin{array}{l}\text { Strengthening the } \\
\text { cooperation system of local } \\
\text { communities and schools } \\
\text { by revitalizing the } \\
\text { community }\end{array}$ & $\begin{array}{l}\text { Building local communities by securing the connection } \\
\text { between villages and schools }\end{array}$ \\
\hline $\begin{array}{l}\text { Region } \\
\text { Region }\end{array}$ & $\begin{array}{l}\text { Autonomous Region to } \\
\text { Autonomous Region MOU }\end{array}$ & $\begin{array}{l}\text { Sharing programs and know-how through cooperation } \\
\text { between autonomous district centers and creating a forum } \\
\text { for discussion }\end{array}$ \\
\hline
\end{tabular}

\subsection{Improvement Measures in Terms of Service Learning Operation: Support System Level}

The suggestion to build a service learning support system is shown in the following [Table 4].

[Table 4] Various Conditions and Plans to Build a Support System

\begin{tabular}{|l|l|}
\hline \multicolumn{1}{|c|}{ Main plan } & \multicolumn{1}{|c|}{ Contents } \\
\hline $\begin{array}{l}\text { Joint responsibility } \\
\text { for safety issues }\end{array}$ & $\begin{array}{l}\text { Safety issues in student movement and lead during external activities are } \\
\text { undermining service learning. } \\
\text { Institutional efforts to realize common responsibilities of schools, autonomous }\end{array}$ \\
\hline
\end{tabular}




\begin{tabular}{|c|c|}
\hline & $\begin{array}{l}\text { regions, and communities in providing transportation and dispatching personnel } \\
\text { in charge of safety } \\
\text { Establish cooperation system related to student safety through business } \\
\text { agreement method such as MOU }\end{array}$ \\
\hline $\begin{array}{l}\text { Budget allocation } \\
\text { for service learning }\end{array}$ & $\begin{array}{l}\text { Need to allocate school budget for service learning operation } \\
\text { Support for school and school board service learning research and program } \\
\text { development costs }\end{array}$ \\
\hline $\begin{array}{l}\text { Building a physical } \\
\text { space platform }\end{array}$ & $\begin{array}{l}\text { Requires a platform of physical space to interact with schools and schools, } \\
\text { schools and boroughs, and communities. } \\
\text { Unused classrooms in schools, autonomous district centers, etc. }\end{array}$ \\
\hline $\begin{array}{l}\text { Establishing an } \\
\text { i } \mathrm{n} \mathrm{t} \text { e } \mathrm{r} \text { a } \mathrm{c} \text { i } \mathrm{v} \text { e } \\
\text { information sharing } \\
\text { platform to identify } \\
\text { human and } \\
\text { material resources }\end{array}$ & $\begin{array}{l}\text { It is necessary to upgrade the information sharing site ( } 1365 \text { volunteer portal, } \\
\text { etc.) so that information from the autonomous district centers, local } \\
\text { organizations, and schools can be shared organically. } \\
\text { In other words, it is necessary to improve the interactive system so that the } \\
\text { information related to the school's service learning, the curriculum connection, } \\
\text { and the volunteer programs of autonomous regions and local organizations are } \\
\text { well matched. }\end{array}$ \\
\hline $\begin{array}{l}\text { Ministry of } \\
\mathrm{E} \mathrm{d} \mathrm{u} \mathrm{c} \mathrm{a} \mathrm{t} \mathrm{i} \mathrm{o} \mathrm{n} \mathrm{,} \\
\text { Education (Support) } \\
\text { Agency's interest } \\
\text { and effort }\end{array}$ & $\begin{array}{l}\text { Training for teachers and principals to raise awareness of service learning and } \\
\text { share methods } \\
\text { Support for research and program development to promote service learning } \\
\text { Ongoing research on how to record service learning } \\
\text { Efforts to support administrative work, including official documents related to } \\
\text { service learning }\end{array}$ \\
\hline
\end{tabular}

\section{Discussion and Conclusion}

The researcher has considered the problems of school service learning and looked at various ways to improve them. The results were discussed and summarized as follows. First, for practical operation of service learning, cooperation between the managers must be diverse. Recognizing the meaning of service learning and the necessity of educational cooperation for this, in practice, it was rare that cooperation was well established and that volunteer activities were carried out organically. This means that service learning is recognized as the work of some teachers, and especially high school has difficulties in actual implementation due to the entrance examination. To overcome these difficulties, it is necessary to grasp the perceptions of each person in charge[18] and agree to each other to establish a channel through which various cooperation can be made so that service learning can be accomplished with the same purpose.

Second, professional organizations are needed and their roles need to be specified so that cooperation between the school and the community can continue. In the connection between the school and the community, the center in the local autonomous region served as a communication and a volunteer mentor was performing, but it was still in poor condition. In 
Discussion on Activation of Youth Service Learning Based on Linkage Between School and Community. Focusing on Human Resources and Operational Aspects

addition, it was difficult to communicate with each step by step until planning and implementing service learning. Therefore, in order for schools, autonomous districts, and communities to properly cooperate in education, it is necessary to strengthen the professionalism of the person in charge, and to concretely present the implementation process step by step.

Third, since the role of the teacher in service learning is important[19], an improvement plan should be prepared for direct factors that induce work stress so as to lead the growth of the teacher while preserving the original characteristics of service learning. The lack of support system for the educational cooperation between teachers, school, community, and autonomous district centers interferes with the professional development of teachers and prevents continuity. Therefore, various measures are required to help teachers lead service learning meaningfully.

Fourth, measures to secure safety should be considered in revitalizing service learning. It was a safety problem that could occur in student mobility as a significant obstacle to various out-of-school service learning. Therefore, various measures for this should be sought.

Finally, the problem of accessibility to service learning resources should be resolved, such as insufficient information on human and material resources related to service learning. It is necessary to provide a physical space where schools, autonomous districts, and communities can meet at any time, and a place for information sharing to exchange necessary information at any time.

\section{References}

[1] D. J. Kim, The Effect of Volunteer Activities on the Development of Sociality in Adolescence, Social Welfare Support Society, (2009), Vol.4, pp.123-146.

[2] S. B. Kim, Expansion of Service Learning and Curriculum Exploration, Curriculum Research, (2004), Vol.22, No.3, pp.229-249.

[3] Y. S. Kim, Y. H. Yeo, Study on the Trends in Life Satisfaction among the Elderly, International Journal of Elderly Welfare Promotion and Management, (2019), Vol.3, No.1, pp.7-12.

[4] J. Eyler, Reflection: Linking Service and Learning-Linking Students and Communities, Journal of Social Issues, (2002), Vol.58, No.3, pp.517-534.

[5] Namgang High School, 2016 Namgang Tabong Activity Report Growing with Sharing and Dreams, Korea: Namgang High School, (2016)

[6] J. Eyler, D. E. Giles, Where's the learning in service-learning?, Korea: Jossey-Bass Higher and Adult Education Series, (1999) 
[7] K. Flecky, L. Gitlow, Service-learning in occupational therapy education, Korea: Jones \& Bartlett Publishers, (2010)

[8] W. G. Cha, M. J. Kim, S. H. Pyo, Y. J. Park, S. H. Kim, Y. S. Lee, A Cross-Curricular Learning Subject and a Curriculum Content Element Connection-Map Development Study, Korea: The Ministry of Education, (2018)

[9] J. S. Chol, Service-Learning Utilization Plan for Citizen Education, Social Studies Education Research, (2012), No.19, pp.71-82.

[10] B. D. Hue, Youth Service Learning Model Research and Help Materials, Korea: Service Learning Center, (2019)

[11] J. C. Kielsmeier, Build a Bridge between Service and Learning, Phi Delta Kappan, (2010), Vol.91, No.5, pp.8-15.

[12] E. H. Warter, J. M. Grossman, An Application of Developmental-Contextualism to Service-Learning, Service-Learning: The Essence of the Pedagogy, USA: Greenwich, CT: Information Age Pub. (2002), pp.83-102.

[13] H. J. Chung, H. Y. Choi, A Study on the Service Quality of Early Childhood Education Institutions: Comparing Public Kindergarten and Private Kindergarten, International Journal of Child Warfare Promotion and Management, (2018), Vol.2, No.2, pp.69-74.

[14] K. S. Lee, Student Service Activities and Development Challenges, Korea: Korea Educational Development Institute, (2014)

[15] H. J. Lim, H. Y. Moon, J. H. Joung, Youth Activity Participation Survey V, Korea: Korea Youth Policy Institute, (2018)

[16] M. S. Son, A Study on How to Use the Community for School Democracy Education and Student Service Activities, Secondary Learning Research, (2019)

[17] Y. J. Hwang, H. J. Jeon, A Study on Youth's Community Participation Model Development, Korea Youth Policy Institute, (2017)

[18] Y. J. Chun, A Study of Perceived Parental Faith-nurturing Activities and Children's Psychological Well-being, International Journal of Child Welfare Promotion and Management, (2019), Vol.3, No.1, pp.15-20.

[19] K. C. Kim, M. J. Kang, B. K. Choi, Y. C. Choi, A Basic Study for Developing Measurement for Early Childhood Teachers' Belief in Creativity Character Education, International Journal of Child Warfare Promotion and Management, (2017), Vol.1, No.1, pp.9-14. 